\title{
Progress in the Production of Biogas from Maize Silage after Acid-Heat Pretreatment
}

\author{
Anna Nowicka (D), Marcin Zieliński (D), Marcin Dębowski * (D) and Magda Dudek (iD \\ Department of Environmental Engineering, Faculty of Geoengineering, University of Warmia and Mazury, \\ 10-720 Olsztyn, Poland; anna.grala@uwm.edu.pl (A.N.); marcin.zielinski@uwm.edu.pl (M.Z.); \\ magda.dudek@uwm.edu.pl (M.D.) \\ * Correspondence: marcin.debowski@uwm.edu.pl
}

Citation: Nowicka, A.; Zieliński, M.; Dębowski, M.; Dudek, M. Progress in the Production of Biogas from Maize Silage after Acid-Heat Pretreatment. Energies 2021, 14, 8018. https:// doi.org/10.3390/en14238018

Academic Editor: John Morken

Received: 29 October 2021

Accepted: 29 November 2021

Published: 1 December 2021

Publisher's Note: MDPI stays neutral with regard to jurisdictional claims in published maps and institutional affiliations.

Copyright: (c) 2021 by the authors. Licensee MDPI, Basel, Switzerland. This article is an open access article distributed under the terms and conditions of the Creative Commons Attribution (CC BY) license (https:// creativecommons.org/licenses/by/ $4.0 /)$.

\begin{abstract}
One of the most effective technologies involving the use of lignocellulosic biomass is the production of biofuels, including methane-rich biogas. In order to increase the amount of gas produced, it is necessary to optimize the fermentation process, for example, by substrate pretreatment. The present study aimed to analyze the coupled effects of microwave radiation and the following acids: phosphoric $(\mathrm{V})$ acid $\left(\mathrm{H}_{3} \mathrm{PO}_{4}\right)$, hydrochloric acid $(\mathrm{HCl})$, and sulfuric $(\mathrm{VI})$ acid $\left(\mathrm{H}_{2} \mathrm{SO}_{4}\right)$, on the destruction of a lignocellulosic complex of maize silage biomass and its susceptibility to anaerobic degradation in the methane fermentation process. The study compared the effects of plant biomass (maize silage) disintegration using microwave and conventional heating; the criterion differentiating experimental variants was the dose of acid used, i.e., $10 \% \mathrm{H}_{3} \mathrm{PO}_{4}, 10 \% \mathrm{HCl}$, and $10 \% \mathrm{H}_{2} \mathrm{SO}_{4}$ in doses of $0.02,0.05,0.10,0.20$, and $0.40 \mathrm{~g} / \mathrm{g}_{\mathrm{TS}}$. Microwave heating caused a higher biogas production in the case of all acids tested $\left(\mathrm{HCl}, \mathrm{H}_{2} \mathrm{SO}_{4}, \mathrm{H}_{3} \mathrm{PO}_{4}\right)$. The highest biogas volume, exceeding $1800 \mathrm{~L} / \mathrm{kg}$ Vs, was produced in the variant with $\mathrm{HCl}$ used at a dose of $0.4 \mathrm{~g} / \mathrm{g}_{\mathrm{TS}}$.
\end{abstract}

Keywords: microwave; pretreatment; acid pretreatment; methane fermentation; biogas; lignocellulose

\section{Introduction}

A detailed objective of the "Polish Energy Policy until 2040" is the development of renewable energy sources, including biogas technologies in energy and transport. The document emphasizes that biomass is the only renewable source of a raw material character. Energy use of biomass-both thermal and anaerobic (biogas), in biogas plants, and for the production of biofuels-will increase, and the energy sector should use, in particular, waste biomass [1]. Currently, according to the register of agricultural biogas plants of the Agricultural Market Agency, in 2021 the number of agricultural biogas plants in Poland is 108. According to the presented data, agricultural biogas is becoming an increasingly important participant in the Polish energy market [2].

The use of renewable energy sources is important, not only because it allows for reducing the imported energy volumes, but also because it paves the way for the development of diversified energetics based on locally-available resources [3]. Lignocellulosic biomass represents a cheap, easily-available, and proliferative raw material [4]. Biofuels produced from biomass can offer a solution to the problem of dependence on petroleum and help reduce $\mathrm{CO}_{2}$ emissions to the atmosphere. Reducing the amounts of greenhouse gases released into the atmosphere will contribute significantly to counteracting the global warming effect. One of the most effective technologies involving the use of lignocellulosic biomass is the production of biofuels, including methane-rich biogas [5]. However, in order to use the biogas generated in biogas plants for energy and transport purposes, it is necessary to upgrade the biogas to the quality of biomethane, as a fuel for vehicles. The biogas has to undergo a subsequent treatment of halogenated siloxanes, ammonia, and volatile organic compounds, as well as the separation of gases, mainly $\mathrm{CO}_{2}$. The 
trends in recent years in Polish industrial practice are the separation of $\mathrm{CO}_{2}$ by absorption, adsorption, or biofiltration [6].

Due to the high oxygen to carbon ratio, lignocellulose is a weaker source of energy than fossil fuels; hence, the goal of methane fermentation is to reduce this ratio [7-9]. The advantage of anaerobic digestion lies in the by-products it generates, some of which are valuable chemical compounds, such as organic acids, vanillin, fatty acid methyl esters, fertilizers, and nutrients. In order to increase the amount of gas produced, it is necessary to optimize the fermentation process by, e.g., substrate pretreatment. Despite the fact that these treatment methods have been addressed in scientific research for many years, there is still a justified need to find an efficient, environmentally friendly, relatively cheap, and simple pretreatment process that would not pose a risk to the formation of large amounts of inhibitor [10].

The commonly applied pre-treatment techniques can be divided into physical, physicochemical, chemical, and biological ones [11,12]. Comparing the methods of pretreatment, attention should be paid to the effects of their operation, especially the degree of delignification, reduction of cellulose crystallinity, destruction of hemicelluloses, increase in the available surface area, and formation of fermentation inhibitors [13]. The deployment of chemical and chemical-thermal disintegration methods of lignocellulosic biomass carries a risk of the formation of fermentation inhibitors, such as furan derivatives and phenolic compounds. Furan derivatives, i.e., furfural and 5-hydroxymethylfurfural (5-HMF), are formed by the dehydration of pentoses and hexoses, respectively. In turn, multiple phenolic compounds (e.g., vanillin, 4-hydroxybenzaldehyde) are generated during lignin breakdown. These compounds are potent inhibitors of methane production $[14,15]$.

Furan and phenolic compounds elicit toxic effects by inhibiting the enzymatic hydrolysis of fermentation bacteria, and contribute to the formation of reactive oxygen species (ROS), which affect cell metabolism and apoptosis. Furfural and 5-HMF inhibit cell growth, induce DNA damage, and inhibit some enzymes of the glycolysis pathway [16]. Phenolic compounds cause damage to bacterial cells by modifying cellular membrane permeability, and thereby causing the leakage of intracellular components and the inactivation of enzymatic systems [17]. It has also been observed that the low-molecular-weight phenolics are more toxic than those having a higher molecular weight [18]. Microorganisms differ between each other in their capability to adapt to and grow in an environment rich in toxic substances. They have also developed various adaptation mechanisms, the task of which is to avoid or repair damages. When it comes to the inhibitors formed during lignocellulose treatment, there are some reports about certain mechanisms of molecular adaptation and activities of certain bacterial groups. Selected bacterial species have been proved capable of converting cis-unsaturated fatty acids into trans-fatty acids at a cellular membrane level [19]. The structural difference in the surface of Gram-positive and Gram-negative bacterial cells affects their resistance to the effect of toxic substances; however, this effect is mainly species-dependent [20]. Certain bacteria can directly convert or damage furan compounds by using them as an additional carbon source, this capability has especially been observed in the case of Gram-negatives aerobes. Under anaerobic conditions, some bacteria can convert furfural and 5-HMF to furfuryl compounds and HMF alcohols [21].

Pretreatment may also affect the fertilization value of the digestate. Chemical pretreatment can affect the quality of the digestate. There are literature reports on the influence of $\mathrm{KOH}$ and $\mathrm{NaOH}$ on the fertilization value of the digestate. The literature shows that the use of $\mathrm{KOH}$ during pretreatment increases the amount of potassium and ammonia in the post-fermentation, while the addition of $\mathrm{NaOH}$ during the treatment may adversely affect the salinity of the soil, due to a significant increase in sodium in the post-fermentation [22].

The pros and cons of the most frequently applied pretreatment methods are collated in Table 1. 
Table 1. Disadvantages and advantages of pretreatment of lignocellulosic substrates $[13,23,24]$.

\begin{tabular}{|c|c|c|}
\hline Pretreatment Method & Advantages & Disadvantages \\
\hline Mechanical disintegration & Cellulose crystallinity reduction & $\begin{array}{c}\text { Energy consumption exceeding the amount of } \\
\text { energy produced }\end{array}$ \\
\hline Steam explosion & $\begin{array}{l}\text { Hemicellulose degradation; lignin } \\
\text { transformation; high cost-effectiveness }\end{array}$ & $\begin{array}{l}\text { Damage to a part of xylans; incomplete } \\
\text { disruption of the lignin-carbohydrate matrix; } \\
\text { formation of inhibitors }\end{array}$ \\
\hline Ammonia fiber explosion & $\begin{array}{l}\text { Increasing the specific surface area; removal } \\
\text { of lignin and cellulose; lack of inhibitors }\end{array}$ & No effects in the case of high-lignin substrates \\
\hline Effects of carbon dioxide & $\begin{array}{l}\text { Increasing the specific surface area; } \\
\text { cost-effectiveness; no inhibitors }\end{array}$ & No effect on lignin and hemicellulose \\
\hline Acidic & $\begin{array}{l}\text { Hydrolysis of hemicellulose to xylose and } \\
\text { other sugars; lignin structure modification }\end{array}$ & $\begin{array}{l}\text { High costs; potential corrosion-inducing effect; } \\
\text { formation of inhibitors }\end{array}$ \\
\hline Alkaline & $\begin{array}{l}\text { Removal of lignin and hemicellulose; } \\
\text { increasing the specific surface area }\end{array}$ & Time-consuming \\
\hline Biological & $\begin{array}{c}\text { Degradation of lignin and hemicellulose; low } \\
\text { energy requirement }\end{array}$ & Very slow course of hydrolysis \\
\hline
\end{tabular}

A less popular method entails microwave-chemical pretreatment, which merges the advantages of thermal and chemical methods. Previous investigations have proven microwave treatment to be more effective than pretreatment via conventional heating [24,25]. Microwave radiation represents a method of electromagnetic energy conversion into heat energy. The capability of microwaves for the volumetric and direct heating of materials enables accelerating the course of the reaction and affecting properties of the heated materials. The selectivity of microwaves towards more polar substances leads to uneven heating of the material's interior, as a result of which, the lignocellulosic complex is degraded. Microwave treatment entails thermal and non-thermal effects elicited by the microwave radiation in the presence of water. The thermal effects consist in the production of internal heat by radiation, due to a local temperature increase, resulting in the formation of so-called rapid local heating. The non-thermal activity of microwaves induces vibrations of polar bonds, resulting in their disruption and in increased rates of chemical and physical processes. The high radiation energy leads to structural changes of the lignocellulosic biomass, increases the specific surface area, reduces the polymerization degree and crystallinity of cellulose, and increases the rate of hemicellulose and lignin hydrolysis. Similar effects are observed in the case of microwave treatments aided with chemical agents. Microwave radiation can be deployed during pretreatment involving the use of acids [26-28] Acid pretreatment leads to the formation of monomeric sugars (xylose, mannose, arabinose, galactose, and glucose), followed by the depolymerization of cellulose. Cellulose is broken down to form celooligosaccharides, which are then hydrolyzed to monomeric sugars [29-31]. A microwave-pretreated substrate features a higher rate of hydrolysis and a high content of soluble sugars in the hydrolysate [26-28,32]. Zhu et al. researched microwave-assisted sodium hydroxide and sulfuric acid pretreatment of lignocellulosic biomass. Microwave pretreatment was more efficient than conventional heating [28] According to the literature, the effect of using microwave radiation on increasing the amount of secreted sugars is impressive, while the effect of microwave treatment on biogas production is not entirely clear [31]. Jackowiak achieved a $68 \%$ increase in biogas production from switchgrass and $28 \%$ for wheat straw using microwave treatment $[33,34]$. Similarly, Kan et al., for brewer's spent grain after the use of microwaves, reported a $52 \%$ increase in the amount of biogas. Sapci, on the other hand, did not record an increase in biogas production when using microwave treatment in a temperature range from 200 to $300{ }^{\circ} \mathrm{C}$ [35]. 
In Poland, methane fermentation of plant biomass is responsible for $13-32 \%$ of the produced biogas. Maize is a popular raw material for the production of biogas, according to the estimates of the Polish Corn Producers Association, the acreage of maize production in Poland in 2018 amounted to approximately 1,191,000 ha. This means that it is one of the most popular plants in the country. The advantage of maize is that it is characterized by high yields per hectare and good susceptibility to ensilage, and it guarantees stable biogas production [36]. Although maize is such a common source of biomass, literature reports on the impact of microwave or a combined (microwave-chemical) treatment on the methane fermentation process of maize silage are very scarce. Most of the available reports focus on the use of thermal treatments based on conventional heating.

The present study aimed to analyze the coupled effects of microwave radiation and the following acids: phosphoric $(\mathrm{V})$ acid $\left(\mathrm{H}_{3} \mathrm{PO}_{4}\right)$, hydrochloric acid $(\mathrm{HCl})$, and sulfuric (VI) acid $\left(\mathrm{H}_{2} \mathrm{SO}_{4}\right)$ on the destruction of a lignocellulosic complex of maize silage biomass and its susceptibility to anaerobic degradation in the methane fermentation process.

\section{Materials and Methods}

\subsection{Study Scheme}

The study compared the effects of plant biomass (maize silage) disintegration using microwave and conventional heating. Preliminary investigations, were aimed at determining parameters of thermal hydrolysis, depending on the heating method deployed, the goal of which was to establish the shortest timespan and the lowest temperature of disintegration process that ensured the highest effectiveness of anaerobic biomass conversion. The criteria used to establish optimal time and temperature, included the amount of glucose released to the solution during thermal hydrolysis and the volume of biogas produced during methane fermentation of the processed material. The mass balance of glucose dissolution was also measured. Statistica 12.0 software was used to estimate $\mathrm{C}_{\mathrm{e}}$ coefficients (concentration of saturation after a given time) and k constant (reaction rate constant), taking into account the concentration of the released glucose and depending on the duration and temperature of maize silage pretreatment. The highest value of reaction rate constant $\mathrm{k}$ (chemical reaction rate constant, in first order reactions, $\mathrm{d}^{-1}$ ) was obtained at the pretreatment temperature of $150{ }^{\circ} \mathrm{C}$ and duration of $20 \mathrm{~min}$.

The study used acid-thermal pretreatment of a lignocellulosic substrate at a temperature and time established in the preliminary investigations. The criterion differentiating experimental variants was the dose of acid used, i.e., $10 \% \mathrm{H}_{3} \mathrm{PO}_{4}, 10 \% \mathrm{HCl}$, and $10 \% \mathrm{H}_{2} \mathrm{SO}_{4}$ in doses of $0.02,0.05,0.10,0.20$, and $0.40 \mathrm{~g} / \mathrm{g}_{\mathrm{TS}}$. The pretreated substrate was subjected to biogas trials with respirometric kits.

\subsection{Experimental Material}

The experiment was carried out with maize silage derived from a research station of the University of Warmia and Mazury in Olsztyn, Poland. Its characteristics are presented in Table 2.

Table 2. Characteristics of the maize silage used in the experiment.

\begin{tabular}{ccc}
\hline Parameter & Unit & Value \\
\hline Total solids $^{1}$ & $\mathrm{mg} / \mathrm{g}_{\mathrm{TS}}$ & $360.0 \pm 11.0$ \\
Volatile solids $^{2}$ & $\mathrm{mg} / \mathrm{g}_{\mathrm{VS}}$ & $326.0 \pm 9.1$ \\
Cellulose $^{3}$ & $\%_{\mathrm{TS}}$ & $20.1 \pm 0.5$ \\
Hemicellulose $^{3}$ & $\%_{\mathrm{TS}}$ & $14.6 \pm 0.3$ \\
Lignin $^{3}$ & $\%_{\mathrm{TS}}$ & $2.6 \pm 0.1$ \\
\hline
\end{tabular}

${ }^{1}$ Content of total solids (TS); ${ }^{2}$ Content of volatile solids (VS); ${ }^{3}$ Percentage content of cellulose/hemicellulose/lignin in total solids. 
Total solids and volatile solids were measured using the gravimetric method. Amounts of cellulose, hemicellulose, and lignin contents in the were determined using the procedure developed by van Soest [37]. The determination consisted of chemical fractionation using neutral and acid detergents, resulting in the determination of neutral-detergent fiber (NDF), acid-detergent fiber (ADF), and acid-detergent lignin (ADL) contents.

Cellulose content:

$$
\text { Cellulose }=\mathrm{ADF}-\mathrm{ADL}
$$

Hemicellulose content:

$$
\text { Hemicellulose }=\mathrm{NDF}-\mathrm{ADF}
$$

Lignin content:

$$
\text { Lignin }=\text { ADL }
$$

\subsection{Substrate Pretreatment}

The substrate was disintegrated in a device having the form of a grinder with a perforated drum mounted in a sealed casing. The revolving speed of the drum was $30 \mathrm{rpm}$. The substrate was disintegrated into particles of 2 to $5 \mathrm{~mm}$. The native disintegrated substrate was hydrated to a $90 \%$ moisture content and then subjected to thermal-acidic pretreatment.

Individual acids were fed into thermal reactors in five various doses, i.e., $0.02 \mathrm{~g} / \mathrm{g}_{\mathrm{TS}}$, $0.05 \mathrm{~g} / \mathrm{g}_{\mathrm{TS}}, 0.10 \mathrm{~g} / \mathrm{g}_{\mathrm{TS}}, 0.20 \mathrm{~g} / \mathrm{g}_{\mathrm{TS}}$, and $0.40 \mathrm{~g} / \mathrm{g}_{\mathrm{TS}}$, and the results obtained were compared with those obtained for the control sample (without the addition of chemical reagents). Substrate pretreatment with a chemical reagent consisted in transferring the prepared raw material with an acid solution $\left(\mathrm{H}_{3} \mathrm{PO}_{4}, \mathrm{HCl}, \mathrm{H}_{2} \mathrm{SO}_{4}\right)$ into pressure vessels and heating it for $20 \mathrm{~min}$ at a temperature of $150{ }^{\circ} \mathrm{C}$.

Thermal hydrolysis was conducted, deploying two heating technologies. The hydrothermal microwave treatment was performed using a Mars-Solvent Extraction system (CEM), with the output power regulated to $1600 \mathrm{~W}$ and microwave radiation frequency of 2.45 GHz. Experiments were carried out in Easy Prep type Teflon vessels having a volume of $115 \mathrm{~cm}^{3}$ (Figure 1).

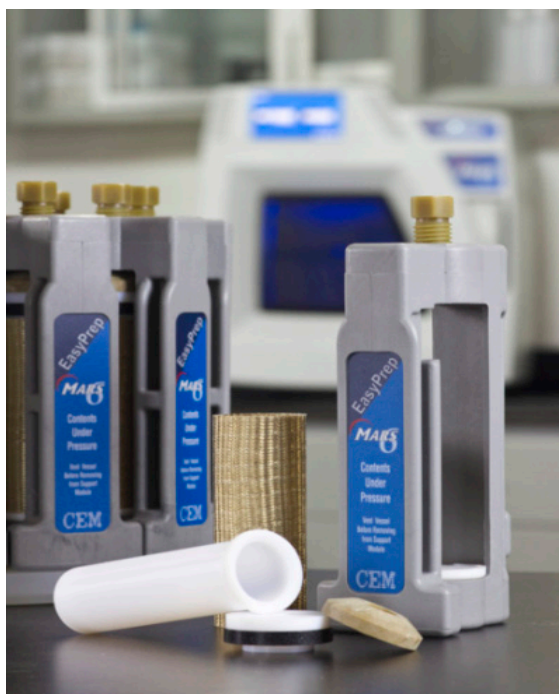

(a)

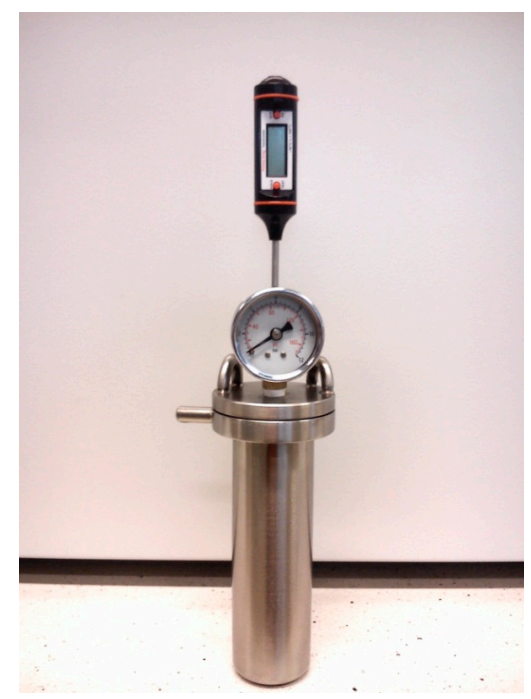

(b)

Figure 1. (a) Easy Prep Teflon vessels and (b) own-design thermal reactor. 
In turn, the thermal hydrolysis with conventional heating was conducted using owndesign thermal reactors made of acid steel and designed in such a way that their dimensions did not differ from those of the Easy Prep vessels used for the microwave digestion of the samples (Figure 1). The conventional heating of the plant material was conducted using a four-station Laboplay $\mathrm{O} 420 \mathrm{E}$ oil bath with silicone oil as a heating medium. The conditions of the thermal hydrolysis performed via conventional and microwave heating were the same. The heating time and temperature were controlled to ensure identical parameters of thermal hydrolysis in both devices.

\subsection{Experimental Procedures}

The scope of the analyses included direct and indirect determinations of disintegration effectiveness. The amount of soluble sugars released to the solution during hydrothermal depolymerization was measured by the 3,5-dinitrosalicylic acid (DNS) method (Miller, 1959) [38]. After adding DNS and distilled water to the hydrolysate, the sample was mixed and heated for $3 \mathrm{~min}$ in a boiling water bath. Reaction with DNS reagent produces red-brown products; the concentration of colored products was determined by measuring the absorbance of the solution at $540 \mathrm{~nm}$ with a UV-VIS DR 6000 spectrophotometer (Hach Lange) against a blank. A sample for soluble sugars assay was prepared by filtering the dissolved plant material through a membrane filter with a pore diameter of $1.2 \mu \mathrm{m}$.

The yield of hydrolysis was computed using the following formula [39]:

$$
\text { Hydrolysis yield }=\frac{c \times 0.9}{p} \times 100[\%]
$$

where

$c$ - concentration of reducing sugars $[\mathrm{g} / \mathrm{L}]$,

$p$-content of cellulose and hemicellulose in the native material (\%),

0.9 - coefficient of monosaccharides conversion to polysaccharides.

The amount of phenolic compounds after hydrothermal depolymerization was assayed with cuvette tests (method with 4-nitroaniline) according to Hach (LCK 345).

The quantification of furfural and 5-HMF was carried out using high-performance liquid chromatography, using a Sykam HPLC system, which includes: S 1125 HPLC Pump System, S 5300 Sample Injector, and S 3345 PDA Detector S 4115 Column oven. The separation of the analyte components was carried out on a Zorbax SB-C18 column $(4.6 \times 150 \mathrm{~mm})$ from Agilent P.N. 883 975-902. In order to establish the conditions of the analyte separation, a stock solution was prepared in which the concentrations of the components were $0.5 \mathrm{~g}$ /L furfural (Sigma-Aldrich SKU: 185914; CAS: 98-01-1) and $0.5 \mathrm{~g} / \mathrm{L}$ 5-HMF (Sigma-Aldrich SKU: 53407; CAS: 67-47-0).

Good separation of compounds in the mixture was obtained for the $\mathrm{CH}_{3} \mathrm{OH}: \mathrm{H}_{2} \mathrm{O}$ mobile phase $(1: 1, v / v)$, flowing at a volumetric flow rate of $0.300 \mathrm{~mL} / \mathrm{min}$, and for a sample loading volume of $20 \mu \mathrm{L}$. The mobile phase was filtered before measurements on membrane filters with pore diameters not exceeding $0.22 \mu \mathrm{m}$. The effectiveness of the acidic pretreatment was analyzed indirectly by respirometric measurements of the degradation of processed biomass under conditions of mesophilic methane fermentation. After complete thermal hydrolysis, the substrate was transferred to control-recording OxiTop systems (WTW), consisting of reaction tanks tightly connected with measuring and registering devices. The tanks were inoculated with anaerobic sludge from an agricultural biogasproducing plant fed with maize silage. The amount of prepared substrate added to $100 \mathrm{~cm}^{3}$ of the sludge was adjusted so as to ensure an initial load of $5 \mathrm{~g}_{\mathrm{Vs}} / \mathrm{L}$ (concentration of volatile solids). Next, the samples were purged with nitrogen to ensure anaerobic conditions. Substrate retention time was 40 days; the necessary measurement time was established based on the amount of biogas produced. It was assumed that the whole degradable matter had been digested when three consecutive values of daily biogas production did not differ by more than $2 \%$. The pressure measurements were made using the analyzer at $15-\mathrm{min}$ intervals; the pressure measurements inside the chamber allowed for the determination 
of the process speed. Using the Statistica 12.0 program, the reaction rate constants were determined on the basis of the obtained experimental data, using the non-linear regression method. The iterative method was used, in which at each iteration step the function was replaced by a linear differential with respect to the determined parameters. With the determined parameters, the coefficient of compliance $\varphi 2$ was adopted as a measure of the curve fit to the experimental data. This coefficient is the ratio of the sum of squared deviations of values calculated on the basis of the determined function from experimental values to the sum of squares of deviations of experimental values from the mean value. The lower the value of the $\varphi 2$ coefficient, the better the capability. The model was adjusted to the experimental points in such a way that the compliance coefficient did not exceed 0.2.

The constant $\mathrm{k}$ was calculated from the formula:

$$
\mathrm{C}=\left(\mathrm{C}_{\mathrm{e}}-\exp ^{-\mathrm{kt}}\right)
$$

where

$\mathrm{C}$-concentration after time $\mathrm{t}$

$\mathrm{C}_{\mathrm{e}}$-maximum concentration

The measuring systems analyzed changes in the partial pressure in the tank triggered by biogas production in the anaerobic processes of microorganisms. The measuring system consisted of a reaction tank and a control-registering device placed in a thermostating cabinet, with the hysteresis not exceeding $\pm 0.5^{\circ} \mathrm{C}$. The measurements were performed at a temperature of $36{ }^{\circ} \mathrm{C}$, and the values of partial pressure in the reaction tank were registered every $15 \mathrm{~min}$. The quality analysis of the biogas produced was conducted using Agilent 7890A GC gas chromatograph with a TCD detector and included determinations of the percentage contents of methane $\left(\mathrm{CH}_{4}\right)$, carbon dioxide $\left(\mathrm{CO}_{2}\right)$, oxygen $\left(\mathrm{O}_{2}\right)$, hydrogen $\left(\mathrm{H}_{2}\right)$, and nitrogen $\left(\mathrm{N}_{2}\right)$. Main parameters of the method: front detector TCD-250 $\mathrm{C}$, back detector TCD-250 ${ }^{\circ} \mathrm{C}$, analysis time $9 \mathrm{~min}$, gas sampling valve-1 mL, column: $6 \mathrm{Ft}$ 1/8 2 mm MolSieve 5A 60/80 Ultimetal, 9 Ft 1/8 2 mm Porapak Q 80/100 Ultimetal, 3 Ft 1/8 2 mm HayeSep Q 80/100 Ultimetal, 6 Ft 1/8 2 mm HayeSep Q 80/100 Ultimetal

The basis for the calculations in the respirometric tests carried out with the OxiTop kits was the ideal gas equation:

$$
n=\frac{p \times V}{R \times T}
$$

where

$n$-number of moles of gas (mol)

$p$-gas pressure $(\mathrm{Pa})$

$V$-gas volume $\left(\mathrm{m}^{3}\right)$

$R$-universal gas constant $(8.314 \mathrm{~J} / \mathrm{mol} \cdot \mathrm{K})$

$T$-temperature $(\mathrm{K})$

Avogadro's law was used to calculate the amount of gas produced, which assumes that under normal conditions, described by a temperature of $273 \mathrm{~K}$ and a pressure of $1013 \mathrm{hPa}$, one mole of gas takes $22.4 \mathrm{~L}$.

$$
V=n \cdot V_{m o l}
$$

where

$V$-gas volume (L)

$n$-number of moles of gas (mol)

$V_{\text {mol }}$-molar volume of gas (L)

All the physico-chemical analyses in the laboratory part of the experiment and the biogas tests with the respirometric sets were performed in 3 replications.

A Shapiro-Wilk test verified the hypothesis concerning the normal distribution of the examined variables. In order to find the significance of differences between the variables, one-way analysis of variance (ANOVA) was performed. The significance of differences 
between the values obtained for the analyzed variables was determined using the RIR Tukey test. The adopted significance level in the tests was $p=0.05$.

\section{Results and Discussion}

In the present study, the substrate was first mechanically disintegrated and then subjected to the coupled hydrothermal and acid treatment. In order to establish the most effective method of maize silage conditioning, various doses of chemical reagents, added to the substrate, were tested and then the samples were either microwave- or conventionally-heated at a temperature of $150{ }^{\circ} \mathrm{C}$ for $20 \mathrm{~min}$. The temperature and duration of heating were established in the preliminary research and supported by literature data, indicating that lignin and hemicellulose begin to degrade at pretreatment temperatures of $150-180{ }^{\circ} \mathrm{C}$ [40]. Gregg and Saddler proved that heat treatments result, not only in hemicellulose destabilization, but also in lignin dissolution [41]. In turn, Brownell and Saddler recommended avoiding temperatures over $250{ }^{\circ} \mathrm{C}$ during heat treatment [42].

The amount of soluble sugars released to the solution as a result of hydrothermal conditioning with each tested dose of acids was higher than that determined after conventional heating. Biomass pretreatment with sulfuric acid caused a greater release of sugars during the microwave than conventional heating (Figure 2). This was particularly true for the microwave heating with the highest tested dose of $\mathrm{H}_{2} \mathrm{SO}_{4}\left(0.4 \mathrm{~g} / \mathrm{g}_{\mathrm{TS}}\right)$, when the glucose concentration in the solution was 2.04 times higher compared to the treatment variant with conventional heating. In the case of the control sample microwave-heated without acid, the concentration of released glucose reached $96.3 \pm 8.08 \mathrm{mg} / \mathrm{L}$, and increased to $2205.7 \pm 40.18 \mathrm{mg} / \mathrm{L}$ in the best acid dose variant $\left(0.4 \mathrm{~g} / \mathrm{g}_{\mathrm{TS}}\right)$, which accounted for $11.57 \%$ of the theoretical hydrolysis yield and was the highest value noted among all values determined for all acid doses and types (Table 3). Gabhane et al. [43] studied acid pretreatment of banana wastes. They used different power sources: microwave, ultrasonification, and autoclaving. The highest sugar yield was observed in the acid-microwave pretreatment, as in the presented results of the authors' research. Vasconcelos et al. studied a sugarcane biomass pretreatment with diluted $\mathrm{H}_{3} \mathrm{PO}_{4}$, and the maximum saccharification was recorded during the pretreatment at $186^{\circ} \mathrm{C}$ for $8 \mathrm{~min}$ [44]. Kaur and Phutela [45], Lag et al. [46], and Binod et al. [27] also noted an increase in the release of sugars after microwave treatments of paddy straw, coconut husks, and sugarcane, respectively.

Table 3. Hydrolysis yield depending on heating method and acid dose.

\begin{tabular}{|c|c|c|c|}
\hline Acid Dose (g/g $\left.\mathrm{g}_{\mathrm{TS}}\right)$ & $\begin{array}{c}\text { Hydrolysis Yield (Addition } \\
\text { of } \mathrm{HCl})(\%)\end{array}$ & $\begin{array}{c}\text { Hydrolysis Yield (Addition } \\
\left.\text { of } \mathrm{H}_{3} \mathrm{PO}_{4}\right)(\%)\end{array}$ & $\begin{array}{c}\text { Hydrolysis Yield (Addition } \\
\left.\text { of } \mathrm{H}_{2} \mathrm{SO}_{4}\right)(\%)\end{array}$ \\
\hline \multicolumn{4}{|c|}{ Conventional heating } \\
\hline 0.0 & $0.41 \pm 0.00$ & $0.35 \pm 0.02$ & $0.42 \pm 0.04$ \\
\hline 0.02 & $0.63 \pm 0.11$ & $0.57 \pm 0.04$ & $0.48 \pm 0.04$ \\
\hline 0.05 & $0.86 \pm 0.10$ & $0.84 \pm 0.10$ & $0.69 \pm 0.02$ \\
\hline 0.1 & $1.38 \pm 0.14$ & $0.82 \pm 0.05$ & $1.07 \pm 0.03$ \\
\hline 0.2 & $2.58 \pm 0.22$ & $1.69 \pm 0.09$ & $2.89 \pm 0.27$ \\
\hline 0.4 & $4.75 \pm 0.38$ & $1.71 \pm 0.07$ & $5.70 \pm 0.27$ \\
\hline \multicolumn{4}{|c|}{ Microwave heating } \\
\hline 0.0 & $0.51 \pm 0.02$ & $0.45 \pm 0.02$ & $0.51 \pm 0.04$ \\
\hline 0.02 & $1.45 \pm 0.07$ & $1.01 \pm 0.03$ & $0.72 \pm 0.06$ \\
\hline 0.05 & $2.96 \pm 0.25$ & $1.78 \pm 0.08$ & $0.82 \pm 0.03$ \\
\hline 0.1 & $4.44 \pm 0.44$ & $2.30 \pm 0.17$ & $1.64 \pm 0.02$ \\
\hline 0.2 & $5.95 \pm 0.53$ & $6.72 \pm 0.33$ & $8.98 \pm 0.19$ \\
\hline 0.4 & $10.84 \pm 0.66$ & $6.91 \pm 0.20$ & $11.57 \pm 0.22$ \\
\hline
\end{tabular}




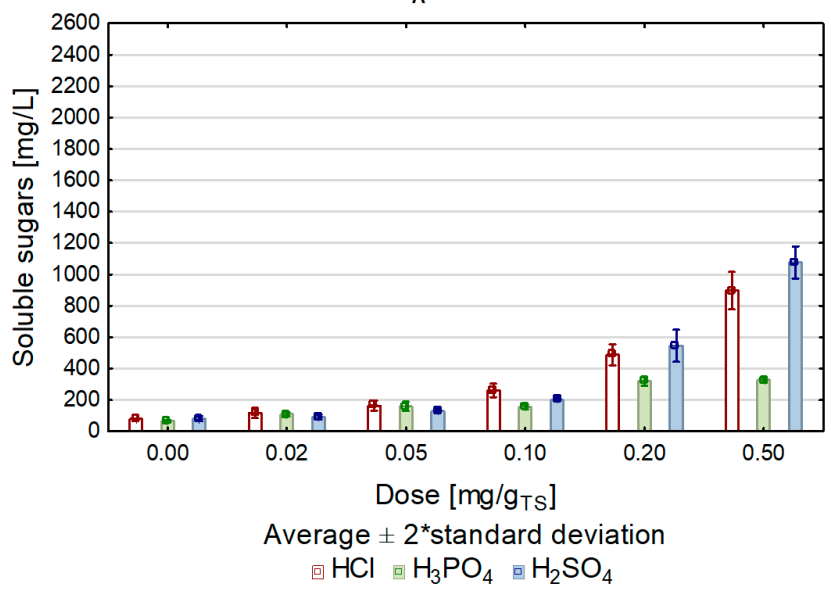

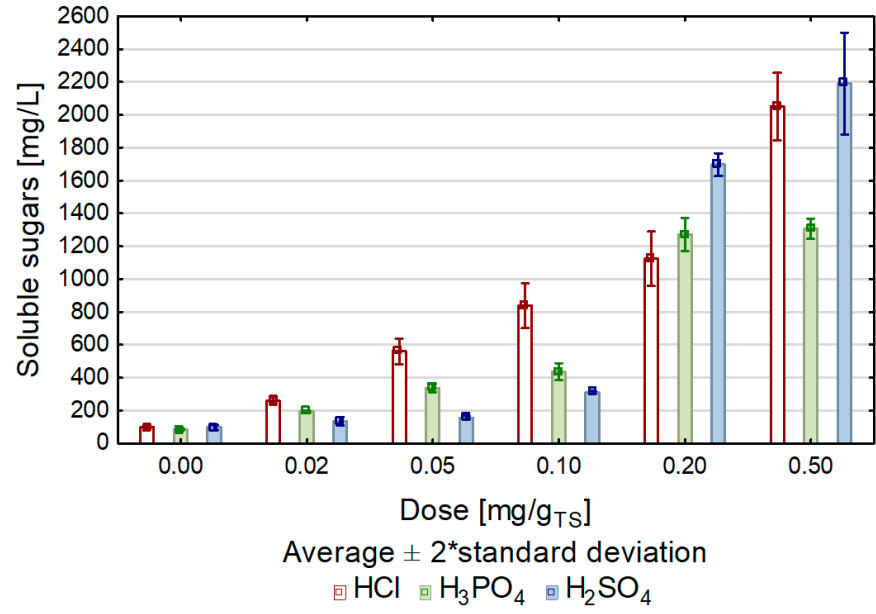

Figure 2. Content of soluble sugars depending on the heating method and acid dose ((A)—conventional, (B)—microwave).

When deploying thermal hydrolysis, attention should be paid to the possibility of adverse effects, such as the production of phenolic and furan compounds that elicit toxic effects and inhibit the growth of methanogenic bacteria [47]. Diaz et al., who investigated the effectiveness of bioethanol production from sunflower stems, determined the contents of non-saccharide products of thermal pretreatment, including furfural and 5-HMF. They demonstrated an increase in the contents of the analyzed compounds at pretreatment temperatures above $190^{\circ} \mathrm{C}$; however, they reported that their content in the hydrolysate was relatively low compared to the predicted content computed based on the loss of pentoses in the substrate [48]. 5-HMF and furfural were also detected during acidic pretreatment of lignocellulosic biomass by Manlau et al., in their study addressing the fermentation of sunflower stems. They analyzed eight variants of substrate pretreatment, including acidic pretreatment with $\mathrm{HCl}$ and $\mathrm{FeCl}_{3}$. During the hydrothermal pretreatment conducted at $170{ }^{\circ} \mathrm{C}$ for $1 \mathrm{~h}$ without chemical agents, furfural was released in an amount of $0.7 \mathrm{~g} / 100 \mathrm{~g}_{\mathrm{TS}}$. Its concentration increased in the pretreatment variants with chemical agents added. The pretreatment conducted under the same conditions but with $\mathrm{HCl}$ caused furfural and 5-HMF release at 4.1/100 g $\mathrm{g}_{\mathrm{TS}}$ and $0.4 \mathrm{~g} / 100 \mathrm{~g}_{\mathrm{TS}}$, respectively; whereas, 5HMF was not detected in the substrate subjected to hydrothermal pretreatment without acid addition. The hydrothermal pretreatment with $\mathrm{FeCl}_{3}$ caused furfural and 5-HMF release in the quantities: $2.4 \mathrm{~g} / 100 \mathrm{~g}_{\mathrm{TS}}$ and $0.3 \mathrm{~g} / 100 \mathrm{~g}_{\mathrm{TS}}$, respectively [49]. Many scientists have proven the formation of adverse substances during acidic pretreatment of various types of biomass, e.g., cassava, rice husks, rice straw, spruce, sugar cane, microalgae, and macroalgae. High-temperature pretreatment conducted at $120-240{ }^{\circ} \mathrm{C}$ using $\mathrm{H}_{2} \mathrm{SO}_{4}, \mathrm{HCl}$, or $\mathrm{H}_{3} \mathrm{PO}_{4}$ was reported to contribute to the release of $0.1-13.32 \mathrm{~g} / \mathrm{L}$ of furfural and $0-4.3$ $\mathrm{g} / \mathrm{L}$ of 5-HMF in the mentioned plants [15].

When comparing the present study results with the literature during the experiment, the soluble sugars/furans and soluble sugars/furans and phenols ratio after the addition of acids in doses from 0.02 to $0.1 \mathrm{~g} / \mathrm{g}_{\mathrm{TS}}$ was low, which indicated a large amount of inhibitory compounds, with a small amount of released soluble sugars. In the case of using larger amounts of acids, the ratio increased, the maximum was 3.77 for $\mathrm{H}_{2} \mathrm{SO}_{4}$, in an amount of $0.2 \mathrm{~g} / \mathrm{g}_{\mathrm{TS}}$. (Table 4). As Bondesson et al. reported, the soluble sugars/furans ratio achieved during heat treatment of corn stover at $200^{\circ} \mathrm{C}$ ranged from 2 to 10.4 . A significantly higher value of this ratio, i.e., 26.8 , was reported after acidic pretreatment of spruce at $150{ }^{\circ} \mathrm{C}$ in the presence of $\mathrm{H}_{2} \mathrm{SO}_{4}$ [50]. The literature indicates that the use of dilute acids for pretreatment is too low for furfural and 5-HMF, as was the case in the described experiment, in which $10 \%$ acid was used $[23,51,52]$. 
The use of increasing doses of $\mathrm{H}_{2} \mathrm{SO}_{4}$ and $\mathrm{HCl}$ contributed to the increased concentration of soluble sugars and increased biogas production in the respirometric tests (Figures 2 and 3). This means that the acid doses applied did not result in the release of inhibitors in the amounts likely to significantly hamper methane fermentation. Opposite observations were made during substrate pretreatment with $\mathrm{H}_{3} \mathrm{PO}_{4}$. Despite a proportional increase in glucose concentration in the pretreated solutions to the acid doses applied, the amount of biogas produced in the respirometric tests increased only at acid doses of up to $0.05 \mathrm{~g} / \mathrm{g}_{\mathrm{TS}}$ in the variant with microwave heating and at acid doses of up to $0.02 \mathrm{~g} / \mathrm{g}_{\mathrm{TS}}$ in that with conventional heating. The use of higher acid doses caused a successive decrease in methane fermentation yield, with the highest dose applied resulting in the lowest biogas production for both heating variants. In the case of conventional heating, the fermentation yield decreased by $48.8 \%$, whereas in the case of microwave heating it decreased by $44.9 \%$ (Figure 3). The decrease in biogas production yield was due to the formation of phenolic compounds, furfural, and 5-hydroxymethylfurfural (5-HMF). In the case of the sample pretreated with the highest acid dose, the content of furan compounds increased to $917 \mathrm{mg} / \mathrm{L}$ in the conventional heating variant and to $902 \mathrm{mg} / \mathrm{L}$ in the microwave heating variant. Contents of phenolic compounds in the samples from the respective variants reached $335 \mathrm{mg} / \mathrm{L}$ and $328 \mathrm{mg} / \mathrm{L}$ (Table 4).

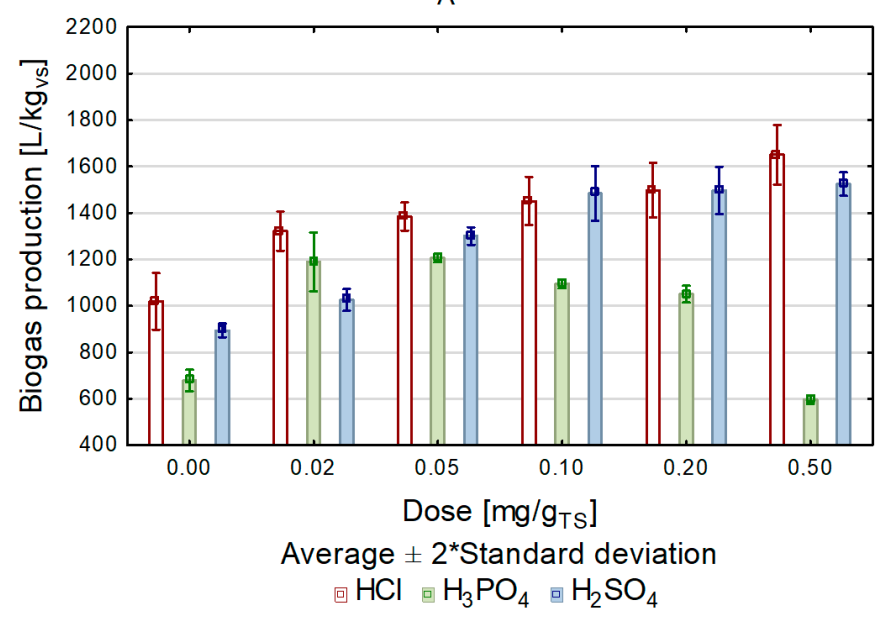

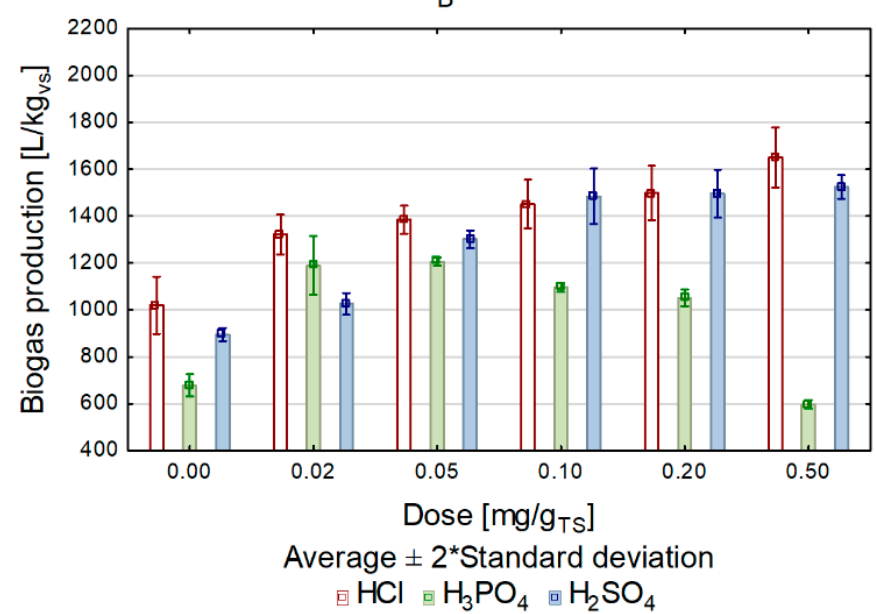

Figure 3. Biogas production depending on the heating method and acid dose ((A)—conventional, (B)—microwave).

Most studies on the thermal pretreatment of lignocellulose show an increase in BMP (biochemical methane potential). Thomas et al. tested BMP from Miscanthus after nontemperature pretreatment with $\mathrm{NaOH}$ and obtained a 55\% increase in BMP [53]. Siddhu tested the BMP of steam-exploded corn stover and, compared with the control sample, received a $\mathrm{BMP}$ increase of 56\% [54]. Microwave researchers also obtained an increase in BMP: Jackowiak, using microwaves at $260{ }^{\circ} \mathrm{C}$ and a pressure of 33 bar obtained an increase of $28 \%$ with switchgrass [31], while Kainthola et al. noted an increase in the amount of methane produced by $100 \mathrm{NmL} \mathrm{CH4/g \textrm {gs }}$ [55]. The authors of the study noted an increase in the amount of biogas generated in each of the tested microwave-heated variants compared to conventionally heated samples. The biggest difference in the amount of biogas between conventional and microwave heating was noted during the conditioning of the substrate with $\mathrm{HCl}$, for a dose of $0.2 \mathrm{~g} / \mathrm{g}_{\mathrm{TS}}$ (Figure 3). 
Table 4. Generation of by-products, depending on heating method and acid dose.

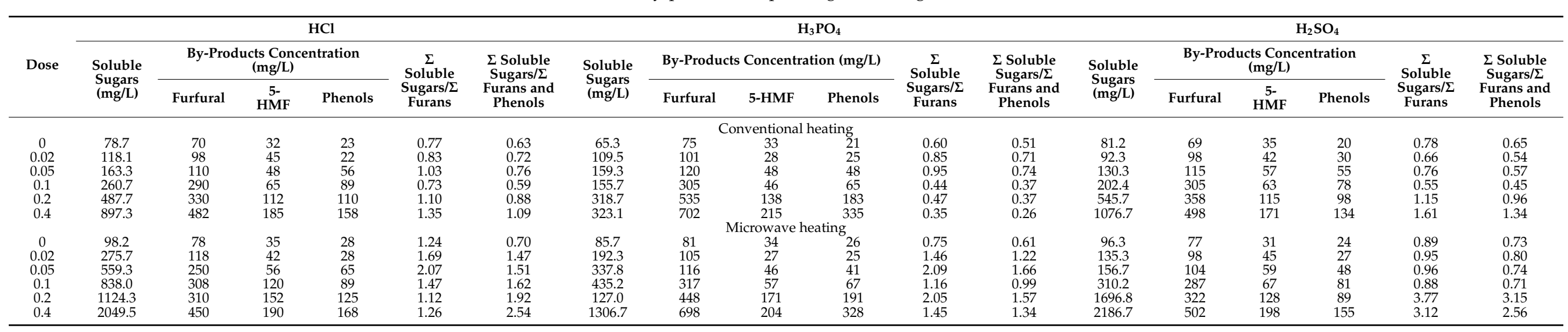


Monlau et al. investigated sunflower oil cake conversion in the methane fermentation process and assessed the effect of acid-heat pretreatment on biogas production and solubilization of total organic carbon, sugars, and protein. They demonstrated a higher methane production for the sample pretreated with dilute sulfuric(VI) acid than for the control sample $\left(195 \mathrm{~mL} / \mathrm{g}_{\mathrm{TS}}\right)$. The highest yield $\left(302 \mathrm{~mL} / \mathrm{g}_{\mathrm{TS}}\right)$ was obtained after acidic pretreatment at a temperature of $170{ }^{\circ} \mathrm{C}$ [56]. The highest volume of biogas in our research, exceeding $1800 \mathrm{~L} / \mathrm{kg}_{\mathrm{VS}}$, was produced using $\mathrm{HCl}$ in the highest tested dose, whereas biogas production using the same dose of $\mathrm{H}_{2} \mathrm{SO}_{4}$ was $10 \%$ lower (Figure 3).

Comparing the two heating methods used, and affecting the tested substrate for the same time with each of the tested variants, it can be concluded that microwave heating resulted in a greater volume of biogas being produced in the methane fermentation process. The same correlation was noted in the case of using acids. In all variants of substrate pretreatment with acids, the volume of biogas in the samples exposed to microwave heating was higher than in those exposed to conventional heating. The greatest biogas volume was produced in the variant with $\mathrm{HCl}$ used in the highest dose (Figure 3). The highest value of the biogas production rate $(\mathrm{r})$ was recorded in the variant with $\mathrm{HCl}$ in a dose of $0.2 \mathrm{~g} / \mathrm{g}_{\mathrm{TS}}$, $\mathrm{r}=0.22 \mathrm{~L} / \mathrm{d}$ (Table 5). The content of methane in biogas in the individual experimental variants did not differ significantly and fluctuated between 55 and $58 \%$ (Figure 4). Reports on the use of microwave treatment to intensify the methane fermentation of lignocellulosic biomass have been inconclusive in confirming its effectiveness. The author of one of these reports, Sapci, studied the production of biogas from barley straw, spring wheat, winter wheat, and oats. He deployed microwave radiation at temperatures of $200{ }^{\circ} \mathrm{C}$ and $300{ }^{\circ} \mathrm{C}$ as a pretreatment method, and subjected the pretreated substrate to methane fermentation under mesophilic conditions for 60 days. The results of his research showed that the microwave treatment did not improve the fermentation yield, and that the increase in process temperature suppressed biogas production [35]. Completely different research results were obtained by Jackowiak et al., who focused their study on optimizing wheat straw methane fermentation by deploying a microwave process [33].

Table 5. Biogas production rate depending on heating method and acid dose.

\begin{tabular}{|c|c|c|c|c|c|c|}
\hline \multirow[b]{2}{*}{$\begin{array}{l}\text { Acid Dose } \\
\left(\mathrm{g} / \mathrm{g}_{\mathrm{vs}}\right)\end{array}$} & \multicolumn{3}{|c|}{ Reaction Rate Constant } & \multicolumn{3}{|c|}{ Biogas Production Rate } \\
\hline & $\begin{array}{c}\text { Addition of } \\
\qquad \mathrm{HCl} \\
\mathbf{k}\left(\mathbf{d}^{-1}\right)\end{array}$ & $\begin{array}{l}\text { Addition of } \\
\qquad \mathrm{H}_{3} \mathrm{PO}_{4} \\
\mathbf{k}\left(\mathrm{d}^{-1}\right)\end{array}$ & $\begin{array}{l}\text { Addition of } \\
\qquad \mathrm{H}_{2} \mathrm{SO}_{4} \\
\mathbf{k}\left(\mathrm{d}^{-1}\right)\end{array}$ & $\begin{array}{c}\text { Addition of } \\
\text { HCl } \\
\mathbf{r}(\mathrm{L} / \mathrm{d})\end{array}$ & $\begin{array}{l}\text { Addition of } \\
\qquad \mathrm{H}_{3} \mathrm{PO}_{4} \\
\mathrm{r}(\mathrm{L} / \mathrm{d})\end{array}$ & $\begin{array}{l}\text { Addition of } \\
\mathrm{H}_{2} \mathrm{SO}_{4} \\
\mathrm{r}(\mathrm{L} / \mathrm{d})\end{array}$ \\
\hline \multicolumn{7}{|c|}{ Conventional heating } \\
\hline 0.0 & 0.27 & 0.27 & 0.21 & 0.12 & 0.08 & 0.09 \\
\hline 0.02 & 0.25 & 0.22 & 0.26 & 0.15 & 0.12 & 0.12 \\
\hline 0.05 & 0.23 & 0.2 & 0.23 & 0.14 & 0.11 & 0.14 \\
\hline 0.1 & 0.25 & 0.23 & 0.23 & 0.16 & 0.11 & 0.16 \\
\hline 0.2 & 0.24 & 0.24 & 0.21 & 0.16 & 0.13 & 0.14 \\
\hline 0.4 & 0.2 & 0.27 & 0.2 & 0.15 & 0.08 & 0.14 \\
\hline \multicolumn{7}{|c|}{ Microwave heating } \\
\hline 0.0 & 0.27 & 0.27 & 0.29 & 0.14 & 0.09 & 0.13 \\
\hline 0.02 & 0.26 & 0.17 & 0.27 & 0.17 & 0.09 & 0.13 \\
\hline 0.05 & 0.21 & 0.18 & 0.25 & 0.15 & 0.13 & 0.15 \\
\hline 0.1 & 0.22 & 0.17 & 0.21 & 0.16 & 0.98 & 0.18 \\
\hline 0.2 & 0.25 & 0.23 & 0.23 & 0.22 & 0.13 & 0.17 \\
\hline 0.4 & 0.2 & 0.27 & 0.16 & 0.17 & 0.09 & 0.13 \\
\hline
\end{tabular}



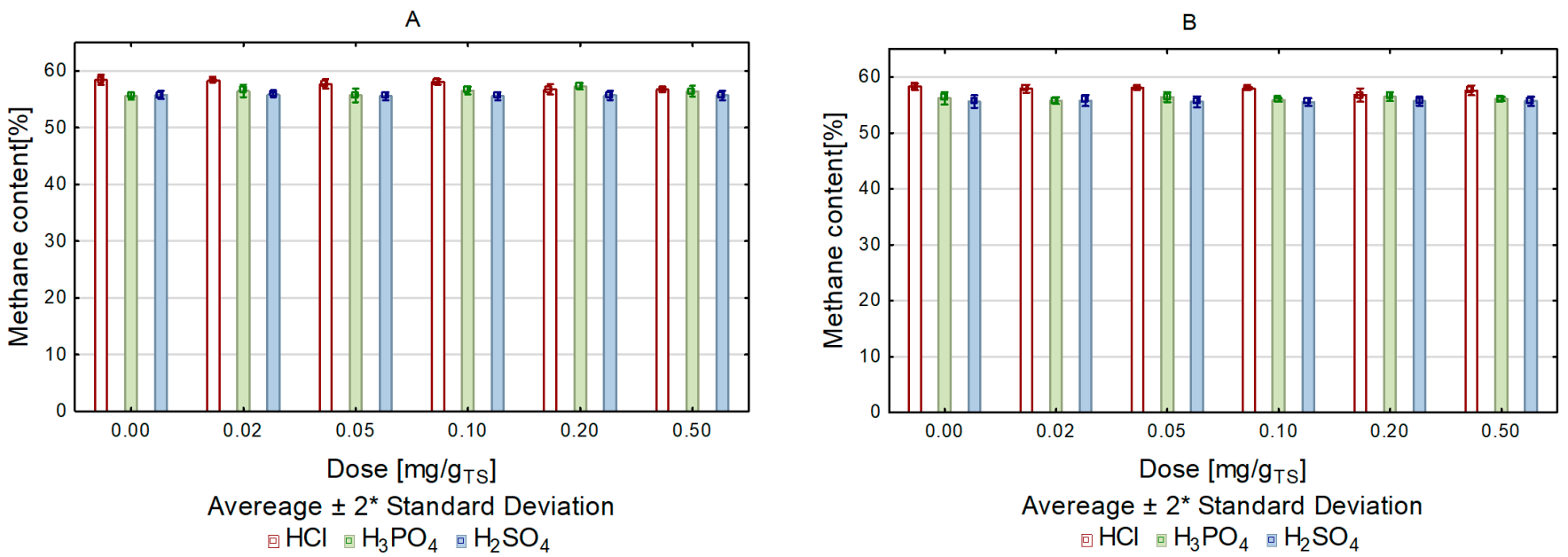

Figure 4. Methane content of biogas, depending on heating method and acid dose ((A)—conventional, (B)—microwave).

Comparing microwave heating to conventional heating, different behaviors and properties were noted in the case of many biological reactions, which, according to scientists, shows the non-thermal effects of microwave radiation [57,58]. In the case of the presented research, the nonthermal effect of microwaves was evident in the difference in the amount of biogas produced between the use of microwave and conventional heating. For each of the tested acids in each dose variant, microwave heating caused an increase in biogas production over conventional heating; according to the theory of the non-terminating microwave effect, microwave activation took place, which increased the speed of the processes. The maximum difference in biogas production between microwave and conventionally heated variants was $19 \%$, during substrate conditioning with $\mathrm{HCl}$, for a dose of $0.2 \mathrm{~g} / \mathrm{g}_{\mathrm{TS}}$ (Figure 3).

\section{Conclusions}

The present study into thermal-chemical pretreatment of lignocellulosic biomass demonstrated that the substrate heating method affected the volume of biogas produced. Microwave heating caused a higher biogas production in the case of all acids tested $(\mathrm{HCl}$, $\mathrm{H}_{2} \mathrm{SO}_{4}$, and $\mathrm{H}_{3} \mathrm{PO}_{4}$ ). The highest biogas volume, exceeding $1800 \mathrm{~L} / \mathrm{kg}_{\mathrm{VS}}$, was produced in the variant with $\mathrm{HCl}$, used in a dose of $0.4 \mathrm{~g} / \mathrm{g}_{\mathrm{TS}}$. The inhibiting effect of by-products (furan and phenolic compounds) was observed during substrate pretreatment with higher $\mathrm{H}_{3} \mathrm{PO}_{4}$ doses. The heating method and acid dose did not affect the methane content of the biogas.

Author Contributions: Conceptualization, A.N. and M.Z.; funding acquisition A.N. and M.D. (Marcin Dẹbowski); investigation, A.N., M.Z., M.D. (Marcin Dẹbowski), M.D. (Magda Dudek); methodology, A.N., M.Z., M.D. (Marcin Dębowski), M.D. (Magda Dudek); supervision, A.N.; visualization, A.N.; writing—original draft, A.N. and M.Z.; writing—review and editing, A.N., M.Z., M.D. (Marcin Debowski). All authors have read and agreed to the published version of the manuscript.

Funding: The manuscript was supported by the National Centre for Sciences from funds granted under decision no. DEC-2012/05/N/ST8/02667. The project was financially supported by Minister of Education and Science in the range of the program entitled "Regional Initiative of Excellence" for the years 2019-2022, project No. 010/RID/2018/19, amount funding 12.000.000 PLN.

Institutional Review Board Statement: Not applicable.

Informed Consent Statement: Not applicable.

Data Availability Statement: Data sharing not applicable.

Conflicts of Interest: The authors declare no conflict of interest. 


\section{References}

1. Dziennik Ustaw. Available online: https:/ /www.dziennikustaw.gov.pl/M2021000026401.pdf (accessed on 17 November 2021).

2. Krajowy Rejestr Wytwórców Biogazu. Available online: https://www.kowr.gov.pl/uploads/pliki/oze/biogaz/rejestr\%20 wytw\%C3\%B3rc\%C3\%B3w\%20biogazu\%20rolniczego\%20z\%20dnia\%2016.04.2021\%20r.pdf (accessed on 17 November 2021).

3. Kazimierowicz, J.; Dzienis, L.; Dębowski, M.; Zieliński, M. Optimisation of methane fermentation as a valorisation method for food waste products. Biomass Bioenergy 2021, 144, 105913. [CrossRef]

4. Dębowski, M.; Kisielewska, M.; Kazimierowicz, J.; Rudnicka, A.; Dudek, M.; Romanowska-Duda, Z.; Zieliński, M. The effects of Microalgae Biomass Co-Substrate on Biogas Production from the Common Agricultural Biogas Plants Feedstock. Energies 2020, 13, 2186. [CrossRef]

5. Kazimierowicz, J.; Dzienis, L. Giant miscanthus as a substrate for biogas production. J. Ecol. Eng. 2015, 16, 139-142.

6. Piechota, G. Multi-Step Biogas Quality Improving by Adsorptive Packed Column System as Application to Biomethane Upgrading. J. Environ. Chem. Eng. 2021, 9, 105944. [CrossRef]

7. Li, P.; Sakuragi, K.; Makino, H. Extraction Techniques in Sustainable Biofuel Production: A Concise Review. Fuel Process. Technol. 2019, 193, 295-303. [CrossRef]

8. Aguilar-Reynosa, A.; Romaní, A.; Rodríguez-Jasso, R.M.; Aguilar, C.N.; Garrote, G.; Ruiz, H.A. Microwave Heating Processing as Alternative of Pretreatment in Second-Generation Biorefinery: An Overview. Energy Convers. Manag. 2017, 136, 50-65. [CrossRef]

9. Alalwan, H.A.; Alminshid, A.H.; Aljaafari, H.A.S. Promising Evolution of Biofuel Generations. Subject Review. Renew. Energy Focus 2019, 28, 127-139. [CrossRef]

10. Wang, D.; Shen, F.; Yang, G.; Zhang, Y.; Deng, S.; Zhang, J.; Zeng, Y.; Luo, T.; Mei, Z. Can Hydrothermal Pretreatment Improve Anaerobic Digestion for Biogas from Lignocellulosic Biomass? Bioresour. Technol. 2018, 249, 117-124. [CrossRef] [PubMed]

11. Kazimierowicz, J.; Bartkowska, I.; Walery, M. Effect of Low-Temperature Conditioning of Excess Dairy Sewage Sludge with the Use of Solidified Carbon Dioxide on the Efficiency of Methane Fermentation. Energies 2021, 14, 150. [CrossRef]

12. Sindhu, R.; Binod, P.; Pandey, A. Biological Pretreatment of Lignocellulosic Biomass-An Overview. Bioresour. Technol. 2016, 199, 76-82. [CrossRef]

13. Hendriks, A.T.W.M.; Zeeman, G. Pretreatments to Enhance the Digestibility of Lignocellulosic Biomass. Bioresour. Technol. 2009, 100, 10-18. [CrossRef]

14. Jönsson, L.J.; Martín, C. Pretreatment of Lignocellulose: Formation of Inhibitory by-Products and Strategies for Minimizing Their Effects. Bioresour. Technol. 2016, 199, 103-112. [CrossRef]

15. Monlau, F.; Sambusiti, C.; Barakat, A.; Quéméneur, M.; Trably, E.; Steyer, J.P.; Carrère, H. Do Furanic and Phenolic Compounds of Lignocellulosic and Algae Biomass Hydrolyzate Inhibit Anaerobic Mixed Cultures? A Comprehensive Review. Biotechnol. Adv. 2014, 32, 934-951. [CrossRef] [PubMed]

16. Almeida, J.; Bertilsson, M.; Gorwa-Grauslund, M.F.; Gorsich, S.; Lidén, G. Metabolic Effects of Furaldehydes and Impacts on Biotechnological Processes. Appl. Microbiol. Biotechnol. 2009, 82, 625-638. [CrossRef] [PubMed]

17. Hierholtzer, A.; Chatellard, L.; Kierans, M.; Akunna, J.C.; Collier, P.J. The Impact and Mode of Action of Phenolic Compounds Extracted from Brown Seaweed on Mixed Anaerobic Microbial Cultures. J. Appl. Microbiol. 2013, 114, 964-973. [CrossRef] [PubMed]

18. Mills, T.Y.; Sandoval, N.R.; Gill, R.T. Cellulosic Hydrolysate Toxicity and Tolerance Mechanisms in Escherichia Coli. Biotechnol. Biofuels 2009, 2, 26. [CrossRef]

19. Palmqvist, E.; Hahn-Hägerdal, B. Fermentation of Lignocellulosic Hydrolysates. II: Inhibitors and Mechanisms of Inhibition. Bioresour. Technol. 2000, 74, 25-33. [CrossRef]

20. Cueva, C.; Mingo, S.; Muñoz-González, I.; Bustos, I.; Requena, T.; del Campo, R.; Martín-Álvarez, P.; Bartolomé, B.; MorenoArribas, M.V. Antibacterial Activity of Wine Phenolic Compounds and Oenological Extracts against Potential Respiratory Pathogens. Lett. Appl. Microbiol. 2012, 54, 557-563. [CrossRef]

21. Zhang, Y.; Ujor, V.; Wick, M.; Ezeji, T. Identification, Purification and Characterization of Furfural Transforming Enzymes from Clostridium Beijerinckii NCIMB 8052. Anaerobe 2015, 33, 124-131. [CrossRef]

22. Elalami, D.; Monlau, F.; Carrere, H.; Abdelouahdi, K.; Oukarroum, A.; Zeroual, Y.; Barakat, A. Effect of Coupling Alkaline Pretreatment and Sewage Sludge Co-Digestion on Methane Production and Fertilizer Potential of Digestate. Sci. Total Environ. 2020, 743, 140670. [CrossRef]

23. Sołowski, G.; Konkol, I.; Cenian, A. Production of Hydrogen and Methane from Lignocellulose Waste by Fermentation. A Review of Chemical Pretreatment for Enhancing the Efficiency of the Digestion Process. J. Clean. Prod. 2020, 267, 121721. [CrossRef]

24. Balat, M. Production of Bioethanol from Lignocellulosic Materials via the Biochemical Pathway: A Review. Energy Convers. Manag. 2011, 52, 858-875. [CrossRef]

25. Du, Z.; Zheng, T.; Wang, P.; Hao, L.; Wang, Y. Fast Microwave-Assisted Preparation of a Low-Cost and Recyclable Carboxyl Modified Lignocellulose-Biomass Jute Fiber for Enhanced Heavy Metal Removal from Water. Bioresour. Technol. 2016, 201, 41-49. [CrossRef]

26. Nowicka, A.; Zieliński, M.; Dębowski, M.; Dudek, M.; Rusanowska, P. Progress in the Production of Biogas from Virginia Mallow after Alkaline-Heat Pretreatment. Biomass Bioenergy 2019, 126, 174-180. [CrossRef] 
27. Binod, P.; Satyanagalakshmi, K.; Sindhu, R.; Janu, K.U.; Sukumaran, R.K.; Pandey, A. Short Duration Microwave Assisted Pretreatment Enhances the Enzymatic Saccharification and Fermentable Sugar Yield from Sugarcane Bagasse. Renew. Energy 2012, 37, 109-116. [CrossRef]

28. Zhu, Z.; Rezende, C.A.; Simister, R.; McQueen-Mason, S.J.; Macquarrie, D.J.; Polikarpov, I.; Gomez, L.D. Efficient Sugar Production from Sugarcane Bagasse by Microwave Assisted Acid and Alkali Pretreatment. Biomass Bioenergy 2016, 93, 269-278. [CrossRef]

29. Lorenci Woiciechowski, A.; Dalmas Neto, C.J.; Porto de Souza Vandenberghe, L.; de Carvalho Neto, D.P.; Novak Sydney, A.C.; Letti, L.A.J.; Karp, S.G.; Zevallos Torres, L.A.; Soccol, C.R. Lignocellulosic Biomass: Acid and Alkaline Pretreatments and Their Effects on Biomass Recalcitrance-Conventional Processing and Recent Advances. Bioresour. Technol. 2020, 304, 122848. [CrossRef]

30. Solarte-Toro, J.C.; Romero-García, J.M.; Martínez-Patiño, J.C.; Ruiz-Ramos, E.; Castro-Galiano, E.; Cardona-Alzate, C.A. Acid Pretreatment of Lignocellulosic Biomass for Energy Vectors Production: A Review Focused on Operational Conditions and Techno-Economic Assessment for Bioethanol Production. Renew. Sustain. Energy Rev. 2019, 107, 587-601. [CrossRef]

31. Bichot, A.; Lerosty, M.; Méchin, V.; Bernet, N.; Delgenès, J.P.; García-Bernet, D. Evaluation of Chemical-Free Microwave Pretreatment on Methane Yield of Two Grass Biomass with Contrasted Parietal Content. Energy Convers. Manag. 2021, 229 , 113746. [CrossRef]

32. Naik, G.P.; Poonia, A.K.; Chaudhari, P.K. Pretreatment of Lignocellulosic Agricultural Waste for Delignification, Rapid Hydrolysis, and Enhanced Biogas Production: A Review. J. Indian Chem. Soc. 2021, 98, 100147. [CrossRef]

33. Jackowiak, D.; Bassard, D.; Pauss, A.; Ribeiro, T. Optimisation of a Microwave Pretreatment of Wheat Straw for Methane Production. Bioresour. Technol. 2011, 102, 6750-6756. [CrossRef] [PubMed]

34. Jackowiak, D.; Frigon, J.C.; Ribeiro, T.; Pauss, A.; Guiot, S. Enhancing Solubilisation and Methane Production Kinetic of Switchgrass by Microwave Pretreatment. Bioresour. Technol. 2011, 102, 3535-3540. [CrossRef] [PubMed]

35. Sapci, Z. The Effect of Microwave Pretreatment on Biogas Production from Agricultural Straws. Bioresour. Technol. 2013, 128, 487-494. [CrossRef] [PubMed]

36. Jankowski, K.J.; Dubis, B.; Sokólski, M.M.; Załuski, D.; Bórawski, P.; Szempliński, W. Productivity and Energy Balance of Maize and Sorghum Grown for Biogas in a Large-Area Farm in Poland: An 11-Year Field Experiment. Ind. Crop. Prod. 2020, 148, 112326. [CrossRef]

37. van Soest, P.J.; Robertson, J.B.; Lewis, B.A. Methods for Dietary Fiber, Neutral Detergent Fiber, and Nonstarch Polysaccharides in Relation to Animal Nutrition. J. Dairy Sci. 1991, 74, 3583-3597. [CrossRef]

38. Miller, G.L. Use of Dinitrosalicylic Acid Reagent for Determination of Reducing Sugar. Anal. Chem. 2002, 31, 426-428. [CrossRef]

39. Światek, K.; Lewandowska, M.; Światek, M.; Bednarski, W.; Brzozowski, B. The Improvement of Enzymatic Hydrolysis Efficiency of Rape Straw and Miscanthus Giganteus Polysaccharides. Bioresour. Technol. 2014, 151, 323-331. [CrossRef]

40. Garrote, G.; Domínguez, H.; Parajó, J.C. Hydrothermal Processing of Lignocellulosic Materials. Holz als roh-und Werkst. 1999, 57, 191-202. [CrossRef]

41. Gregg, D.; Saddler, J.N. A Techno-Economic Assessment of the Pretreatment and Fractionation Steps of a Biomass-to-Ethanol Process. Appl. Biochem. Biotechnol. 1996, 57, 711-727. [CrossRef]

42. Brownell, H.; Yu, E.; Saddler, J. Steam-Explosion Pretreatment of Wood: Effect of Chip Size, Acid, Moisture Content and Pressure Drop. Biotechnol. Bioeng. 1986, 28, 792-801. [CrossRef]

43. Gabhane, J.; Prince William, S.P.M.; Gadhe, A.; Rath, R.; Vaidya, A.N.; Wate, S. Pretreatment of Banana Agricultural Waste for Bio-Ethanol Production: Individual and Interactive Effects of Acid and Alkali Pretreatments with Autoclaving, Microwave Heating and Ultrasonication. Waste Manag. 2014, 34, 498-503. [CrossRef] [PubMed]

44. de Vasconcelos, S.M.; Santos, A.M.P.; Rocha, G.J.M.; Souto-Maior, A.M. Diluted Phosphoric Acid Pretreatment for Production of Fermentable Sugars in a Sugarcane-Based Biorefinery. Bioresour. Technol. 2013, 135, 46-52. [CrossRef]

45. Kaur, K.; Phutela, U.G. Enhancement of Paddy Straw Digestibility and Biogas Production by Sodium Hydroxide-Microwave Pretreatment. Renew. Energy 2016, 92, 178-184. [CrossRef]

46. Laghari, S.; Isa, M.; Laghari, A. Delignification of Coconut Husk by Microwave Assisted Chemical Pretreatment. Adv. Environ. Biol. 2015, 9, 1-5.

47. Gossett, J.M.; Stuckey, D.C.; Owen, W.F.; McCarty, P.L. Heat Treatment and Anaerobic Digestion of Refuse. J. Environ. Eng. Div. 1982, 108, 437-454. [CrossRef]

48. Díaz, M.J.; Cara, C.; Ruiz, E.; Pérez-Bonilla, M.; Castro, E. Hydrothermal Pre-Treatment and Enzymatic Hydrolysis of Sunflower Stalks. Fuel 2011, 90, 3225-3229. [CrossRef]

49. Monlau, F.; Sambusiti, C.; Barakat, A.; Guo, X.M.; Latrille, E.; Trably, E.; Steyer, J.-P.; Carrere, H. Predictive Models of Biohydrogen and Biomethane Production Based on the Compositional and Structural Features of Lignocellulosic Materials. Environ. Sci. Technol. 2012, 46, 12217-12225. [CrossRef]

50. Larsson, S. Ethanol from Lignocellulose-Fermentation Inhibitors, Detoxification and Genetic Engineering of Sacchwomyces Cerevkiae for Enhanced Resistance. Ph.D. Thesis, Lund University, Lund, Sweden, 2000.

51. Wyman, C.E.; Dale, B.E.; Elander, R.T.; Holtzapple, M.; Ladisch, M.R.; Lee, Y.Y. Coordinated Development of Leading Biomass Pretreatment Technologies. Bioresour. Technol. 2005, 96, 1959-1966. [CrossRef] [PubMed]

52. Rashid, N.; Lee, K.; Mahmood, Q. Bio-Hydrogen Production by Chlorella Vulgaris under Diverse Photoperiods. Bioresour. Technol. 2011, 102, 2101-2104. [CrossRef] 
53. Thomas, H.L.; Arnoult, S.; Brancourt-Hulmel, M.; Carrère, H. Methane Production Variability According to Miscanthus Genotype and Alkaline Pretreatments at High Solid Content. Bioenergy Res. 2019, 12, 325-337. [CrossRef]

54. Siddhu, M.A.H.; Li, J.; Zhang, J.; Huang, Y.; Wang, W.; Chen, C.; Liu, G. Improve the Anaerobic Biodegradability by Copretreatment of Thermal Alkali and Steam Explosion of Lignocellulosic Waste. BioMed Res. Int. 2016, 2016, 2786598. [CrossRef] [PubMed]

55. Kainthola, J.; Shariq, M.; Kalamdhad, A.S.; Goud, V.V. Enhanced Methane Potential of Rice Straw with Microwave Assisted Pretreatment and Its Kinetic Analysis. J. Environ. Manag. 2019, 232, 188-196. [CrossRef] [PubMed]

56. Monlau, F.; Latrille, E.; da Costa, A.C.; Steyer, J.P.; Carrère, H. Enhancement of Methane Production from Sunflower Oil Cakes by Dilute Acid Pretreatment. Appl. Energy 2013, 102, 1105-1113. [CrossRef]

57. Dębicki, P.; Styłba, S. Oddziaływania Środowiskowe Pół Elektromagnetycznych: Aspekty Fizyczne, Techniczne i Prawne; Akademia Morska: Szczecin, Poland, 2010.

58. Kazimierowicz, J.; Zieliński, M.; Dębowski, M. Influence of the Heating Method on the Efficiency of Biomethane Production from Expired Food Products. Fermentation 2021, 7, 12. [CrossRef] 